\title{
First report of the ectomycorrhizal status of boletes on the Northern Yucatan Peninsula, Mexico determined using isotopic methods
}

\author{
Niles J. Hasselquist • Greg W. Douhan • Michael F. Allen
}

Received: 5 November 2010 / Accepted: 16 December 2010/Published online: 6 January 2011

(C) The Author(s) 2011. This article is published with open access at Springerlink.com

\begin{abstract}
Despite their prominent role for tree growth, few studies have examined the occurrence of ectomycorrhizal fungi in lowland, seasonally dry tropical forests (SDTF). Although fruiting bodies of boletes have been observed in a dry tropical forest on the Northern Yucatan Peninsula, Mexico, their occurrence is rare and their mycorrhizal status is uncertain. To determine the trophic status (mycorrhizal vs. saprotrophic) of these boletes, fruiting bodies were collected and isotopically compared to known saprotrophic fungi, foliage, and soil from the same site. Mean $\delta^{15} \mathrm{~N}$ and $\delta^{13} \mathrm{C}$ values differed significantly between boletes and saprotrophic fungi, with boletes $8.0 \%$ enriched and $2.5 \%$ depleted in ${ }^{15} \mathrm{~N}$ and ${ }^{13} \mathrm{C}$, respectively relative to saprotrophic fungi. Foliage was depleted in ${ }^{13} \mathrm{C}$ relative to both boletes and saprotrophic fungi. Foliar $\delta^{15} \mathrm{~N}$ values, on the other hand, were similar to saprotrophic fungi, yet were considerably lower relative to bolete fruiting bodies. Results from this study provide the first isotopic evidence of ectomycorrhizal fungi in lowland SDTF and emphasize the need for further research to better understand the diversity and ecological importance of ectomycorrhizal fungi in these forested ecosystems.
\end{abstract}

\footnotetext{
N. J. Hasselquist $\cdot$ M. F. Allen

Center for Conservation Biology, University of California,

Riverside, CA 92521, USA
}

\section{G. W. Douhan • M. F. Allen}

Department of Plant Pathology and Microbiology, University of California,

Riverside, CA 92521, USA

\section{N. J. Hasselquist $(\bowtie)$}

Department of Forest Ecology and Management,

Swedish University of Agriculture Sciences (SLU),

SE-901 83 Umeå, Sweden

e-mail: Niles.Hasselquist@seksko.slu.se
Keywords Ectomycorrhizae - Saprotrophic fungi - Tropical dry forest $\cdot$ Stable isotopes $\cdot$ Yucatan Peninsula

\section{Introduction}

Numerous studies have demonstrated that mycorrhizal symbioses are ubiquitous features of terrestrial plant communities (Allen et al. 1995; Smith and Read 2008). Of the two most common mycorrhiza types, arbuscular mycorrhizal (AM) fungi are widespread, forming symbiotic associations with roughly $85 \%$ of all terrestrial plants (Smith and Read 2008). Ectomycorrhizal (EM) fungi, on the other hand, are restricted to a smaller number of host plant species (Allen et al. 1995) and are best known from studies in northern temperate and boreal ecosystems.

In contrast to EM-rich temperate and boreal forests, tropical forests had long been thought to be impoverished in fungal species forming EM associations (Dennis 1970; Pirozynski 1980). This generalization was based on surveys that demonstrated the prevalence of AM trees in wet tropical forests and the concomitant dearth of tree species known to form EM associations (Janos 1983; Redhead 1968; St. John 1980). However, recent mycological studies in wet tropical forests have shown a wide diversity of EM fungi (Henkel et al. 2002 and references therein). Currently, only a few EM studies have been conducted in lowland, seasonally dry tropical forests (SDTF) (Brundrett et al. 1996; Högberg 1992; Thoen and Ba 1989), and to our knowledge, no studies have examined the occurrence of EM fungi in the highly diverse, lowland SDTF of the Yucatan Peninsula and Northern Central America.

Fruiting bodies of boletes (Boletaceae species) have previously been observed at El Eden Ecological Reserve, a lowland SDTF reserve located on the Northern Yucatan 
Peninsula, Mexico (Allen and Rincon 2003). However, the production of bolete fruiting bodies is extremely sporadic in this area. During 15 years of research at El Eden Ecological Reserve, we have observed fruiting bodies of boletes only twice, during the rainy season in 2001 and 2005. Because nearly all bolete species are obligate ectomycorrhizal symbionts, it seems reasonable to expect that EM fungi occur in this forested ecosystem. However, it has been difficult to evaluate the existence of EM fungi in this forested ecosystem because of a previous lack of putative EM fruiting bodies, the highly interspersed distribution of potential host trees, and the complex mixing of root systems. For instance, despite examining plant roots from soil cores taken throughout the Reserve, Allen and Rincon (2003) did not observe readily discernible EM root tips.

Many putative EM taxa have proven difficult to culture, and therefore, their mycorrhizal status cannot be directly proven according to the methods of Koch's postulates. However, differences in carbon and nitrogen isotope ratios $\left(\delta^{13} \mathrm{C}\right.$ and $\delta^{15} \mathrm{~N}$ values) among fungal fruiting bodies of EM and saprotrophic fungi provides a way of determining trophic strategies (ectomycorrhizal vs. saprotrophic) for a broad range of fungi, including fungi whose trophic strategies is uncertain (Hobbie et al. 2001). In general, EM fungi are enriched in ${ }^{15} \mathrm{~N}$ and depleted in ${ }^{13} \mathrm{C}$ relative to co-occurring saprotrophic fungi (Henn and Chapela 2001; Hobbie et al. 1999, 2001; Taylor et al. 2003: Trudell et al. 2004). In this study, we compared the carbon $\left(\delta^{13} \mathrm{C}\right)$ and nitrogen $\left(\delta^{15} \mathrm{~N}\right)$ isotopic signature of bolete fruiting bodies to known saprotrophic fungi, foliage, and soil from the same site in order to determine the trophic status of bolete species in a highly diverse, lowland SDTF on the Northern Yucatan Peninsula.

\section{Methods}

Study-site This study was conducted at the El Eden Ecological Reserve (see Allen et al. 2003), a 2500-ha SDTF reserve located in the northeastern corner of the Yucatan Peninsula, Mexico $\left(21^{\circ} 12^{\prime} 61^{\prime \prime} \mathrm{N}, 87^{\circ} 10^{\prime} 93^{\prime \prime} \mathrm{W}\right)$. The mean annual temperature of the site is $24.2^{\circ} \mathrm{C}$. The region averages $1,500-2,000 \mathrm{~mm}$ annual precipitation, mostly falling during June to December. The landscape is flat, with an elevation of $6 \mathrm{~m}$ asl. The soils at the reserve are extremely thin (often only a few centimeters) and overlie limestone bedrock. Soils are further characterized by ca. $30 \%$ soil organic matter, $\mathrm{pH} 7.5$, bulk density of $0.35 \mathrm{~g} / \mathrm{cm}^{3}$, and the lack of a well-developed mineral soil layer (Allen et al. 2003). The reserve is characterized by high plant diversity (Schultz 2005), and among these species are a number of angiosperm genera known to form EM associations in other tropical forested ecosystems, including Guapira, Neea, Pisonia, and Coccoloba (Haug et al. 2005; Lodge 1996; Tedersoo et al. 2010). Although these genera are rare at the reserve, they are evenly distributed throughout the forest.

Sample collection In October 2005, fruiting bodies of boletes and saprotrophic fungi were collected in a 1-ha area. Collected specimens were classified, using both local, as well as broader taxonomic keys (Bessette et al. 2000; Guzman 2003; Halling and Mueller 1999; Ortiz-Santana et al. 2007). Additionally, a small piece of the cap ( $\sim 5 \mathrm{~g})$ was removed from each boletes fruiting body and stored in a 1.5-ml microcentrifuge tube (SealRite, Germany) containing cetyltrimethylammonium bromide (CTAB) buffer for molecular analyses. The remaining fruiting body tissue was oven-dried $\left(60^{\circ} \mathrm{C}, 24 \mathrm{~h}\right)$ for stable isotope analyses.

Molecular protocols DNA was extracted from bolete fruiting bodies using a modified CTAB method (Gardes and Bruns 1993). The internal transcribed spacer (ITS) region of the ribosomal DNA was sequenced using the primer IST1F in various combinations with primers ITS4 and LR3. The general protocol was $94^{\circ} \mathrm{C}$ for $5 \mathrm{~min}$, followed by 25 cycles of $1 \mathrm{~min}$ at $94^{\circ} \mathrm{C}, 1 \mathrm{~min}$ at $55^{\circ} \mathrm{C}$ and $2 \mathrm{~min}$ at $72^{\circ} \mathrm{C}$, followed by $7 \mathrm{~min}$ at $72^{\circ} \mathrm{C}$. The PCR products were visualized on $1.5 \%$ agarose gels with ethidium bromide. PCR products were cut from gels and cleaned with Zymoclean Gel DNA Recovery Kit (Zymo Research, Orange, CA, USA) before being sequenced. Sequencing was performed with the same primers as above at the Core Instrumentation Facility (CIF) of the University of California at Riverside's Institute of Integrative Genome Biology. Sequences were edited using Sequencher (version 4.6, Gene Codes Corporation, Ann Arbor, MI, USA). Once individual samples were grouped according to sequence type, a general BLAST search was performed in order to aid in the identification of the obtained sequences.

Stable isotope analyses In addition to bolete fruiting bodies, we also collected fruiting bodies of saprotrophic fungi in October 2005. Although fruiting bodies of saprotrophic fungi were abundant, we only report isotopic values for a subset of wood-decomposing and litterdecomposing taxa $(n=6$ species of wood-decomposers and $n=13$ species of litter-decomposing fungi). Wooddecomposing fungi included Cookeina speciosa (Fr.) Dennis, Cyathus colensoi Berk., Scutellinia scutellata (L.) Lambotte, Trametes villosa (Sw.) Kreisel, Xylaria coccophora Mont., and Marasmiellus cubensis (Berk \& M.A. Curtis) Singer. Litter-decomposing fungi included Leucocoprinus birnbaumii (Corda) Singer, Marasmius haematocephalus (Mont.) Fr., Agaricus spp. ( $n=4$ species), Coprinus spp. ( $n=3$ species), Pholiota spp. ( $n=2$ species), 
and Psathyrella spp. ( $n=2$ species). For this study, we also determined the isotopic composition of fruiting bodies of archived boletes collected in $2001(n=10)$. Bolete species gathered in 2001 were collected in a similar way as described above, with the exception that no material was taken for molecular analyses.

Leaf and soil samples were also collected from the same area for isotopic analysis. Sunlit leaf samples were collected from six of the dominant tree species at our site (Caesalpinia gaumeri Greenm., Coccoloba diversifolia Jacq., Esenbeckia pentaphylla (Macfad.) Griseb., Lonchocarpus castilloi Standley, Lysiloma latisiliquum (L.) Benth., and Vitex gaumeri Greenm.). Live leaf samples were collected from the canopy of three trees of each species giving a total of 18 samples. For each individual tree, five mature leaves were collected from the top canopy using a pole tree pruner and pooled into a single sample. Soil samples were randomly collected within the 1-ha area by inserting a $4.5-\mathrm{cm}$ diameter metal corer until we encountered the limestone bedrock (usually $<10 \mathrm{~cm}$ in depth) for a total of 18 samples. Roots were carefully removed from individual cores. Both leaf and soil samples were dried at $70^{\circ} \mathrm{C}$ for $48 \mathrm{~h}$ prior to stable isotope analyses.

Dried samples of entire fungal fruiting bodies, foliage, and soil were ground with a Thomas Wiley mini-mill (Thomas Scientific, Swedesboro, NJ, USA) and analyzed for $\delta^{13} \mathrm{C}$ and $\delta^{15} \mathrm{~N}$. Analyses of carbon $\left(\delta^{13} \mathrm{C}\right)$ and nitrogen $\left(\delta^{15} \mathrm{~N}\right)$ isotope ratios were performed using an elemental analyzer (Model ANCA-SL, Europa Scientific, Ltd., Crewe, UK) connected to a continuous flow isotope ratio mass spectrometer (Model 20/20, Europa Scientific) at the Center for Stable Isotope Biogeochemistry of the University of California, Berkeley. Stable isotope abundances are reported as: $\delta^{15} \mathrm{~N}$ or $\delta^{13} \mathrm{C}(\%)=\left(\mathrm{R}_{\text {sample }} / \mathrm{R}_{\text {standard }}-1\right) \times$ 1,000 , where $\mathrm{R}={ }^{15} \mathrm{~N} /{ }^{14} \mathrm{~N}$ or ${ }^{13} \mathrm{C} /{ }^{12} \mathrm{C}$. The sample ratio is relative to the Vienna PeeDee Belemnite (VPDB) standard for carbon and $\mathrm{N}_{2}$ atmospheric gas for nitrogen.

Student $t$-tests were used to determine significant $(P<$ $0.05)$ differences in isotopic ratios between boletes collected in 2001 and 2005. Isotopic data from fungal fruiting bodies, plant foliage, and soil were subjected to a one-way ANOVA followed by post hoc LSD tests to determine significant $(P<0.05)$ differences among different ecosystem compartments. Statistical analyses were conducted using SPSS statistical software (v.16.0; SPSS, 2007).

\section{Results}

We observed a total of 21 bolete fruiting bodies in 2005, yet many of these fruiting bodies were severely colonized by a Hypomyces species. We excluded fruiting bodies that were visibly colonized by Hypomyces from this study, and therefore, analyzed a total of 11 boletes for molecular phylogeny and isotopic values. In general, bolete fruiting bodies tended to be moderate in size and relatively slender (Fig. 1).The caps ranged in size from 3 to $7 \mathrm{~cm}$, and the stipes were no greater than $2 \mathrm{~cm}$ in diameter. Pores were yellow at maturity, relatively large, and nearly adnate or somewhat depressed around the stipe apex. Stipe was relatively slender, lacked a bulbous base, and nonreticulated. If stipe was reticulated, then only in the upper part with elongated meshes, sometimes taking the appearance of longitudinal ribs. Spore print was brown with olive tinges.

We obtained sequences from all 11 bolete fruiting bodies, and based on sequence similarities, we indentified four distinct taxa. Two taxa consisted of single collections, whereas the other two taxa consisted of three and six independent collections. The closest match for boletes spp. one and four was with an uncultured Boletus species found on root tips of Quercus spp. in a tropical cloud forest in central Mexico (Morris et al. 2009). Based on morphology, all four taxa appeared to belong to the genus Xerocomus (Fig. 1), yet the closest matches in GenBank were less than $90 \%$.

Among the boletes, there was no significant difference in $\delta^{13} \mathrm{C}$ and $\delta^{15} \mathrm{~N}$ values between samples collected in 2005 and archive samples ( $P>0.05$ for both; Fig. 2). Fruiting bodies of boletes and saprotrophic fungi, on the other hand, differed significantly in both $\delta^{15} \mathrm{~N}$ and $\delta^{13} \mathrm{C}$, with boletes $8.0 \%$ enriched and $2.5 \%$ depleted in ${ }^{15} \mathrm{~N}$ and ${ }^{13} \mathrm{C}$, respectively, relative to saprotrophic fungi $(P<0.001$ for both; Table 1; Fig. 2).

The $\delta^{13} \mathrm{C}$ values of wood-decomposing fungi ranged from $-23.3 \%$ to $-22.6 \%$, which was slightly higher than the range for litter-decomposing fungi $(-25.0$ to $-23.3 \%$ ). On the other hand, the $\delta^{13} \mathrm{C}$ values of boletes ranged from $-26.7 \%$ o to $-25.2 \%$, with a mean value of $-26.0 \pm 0.1 \%$ o (Fig. 2). The mean $\delta^{13} \mathrm{C}$ differed significantly among the different ecosystem compartments $\left(\mathrm{F}_{4,71}=175.5, P<0.001\right)$ and increased in the order: foliage $<$ soil $<$ boletes $<$ litterdecomposing fungi $<$ wood-decomposing fungi (Table 1 ).

The $\delta^{15} \mathrm{~N}$ values of wood-decomposing fungi ranged from $0.5 \%$ to $2.4 \%$, with a mean value of $1.5 \pm 0.3 \%$. On the other hand, the $\delta^{15} \mathrm{~N}$ values of boletes varied from $6.2 \%$ to $14.2 \%$, with a mean value of $9.3 \pm 0.5 \%$. Litterdecomposing fungi had $\delta^{15} \mathrm{~N}$ values more similar to wooddecomposing fungi and ranged from $-1.8 \%$ to $3.4 \%$ o (Fig. 2), with a mean value of $1.2 \pm 0.3 \%$. As observed for $\delta^{13} \mathrm{C}$, mean $\delta^{15} \mathrm{~N}$ differed significantly among the different ecosystem compartments $\left(\mathrm{F}_{4,71}=92.9, P<0.001\right)$. However, the mean $\delta^{15} \mathrm{~N}$ ranking was different to that for $\delta^{13} \mathrm{C}$ and increased in the order: litter-decomposing fungi $<$ foliage $<$ wood-decomposing fungi $<$ soil $<$ boletes (Table 1). 
Fig. 1 Fruiting bodies of bolete species found in a seasonally dry tropical forest on the Northern Yucatan Peninsula. a Bolete sp. 1, b Bolete sp. 2, c Bolete sp. 3, d Bolete sp. 4
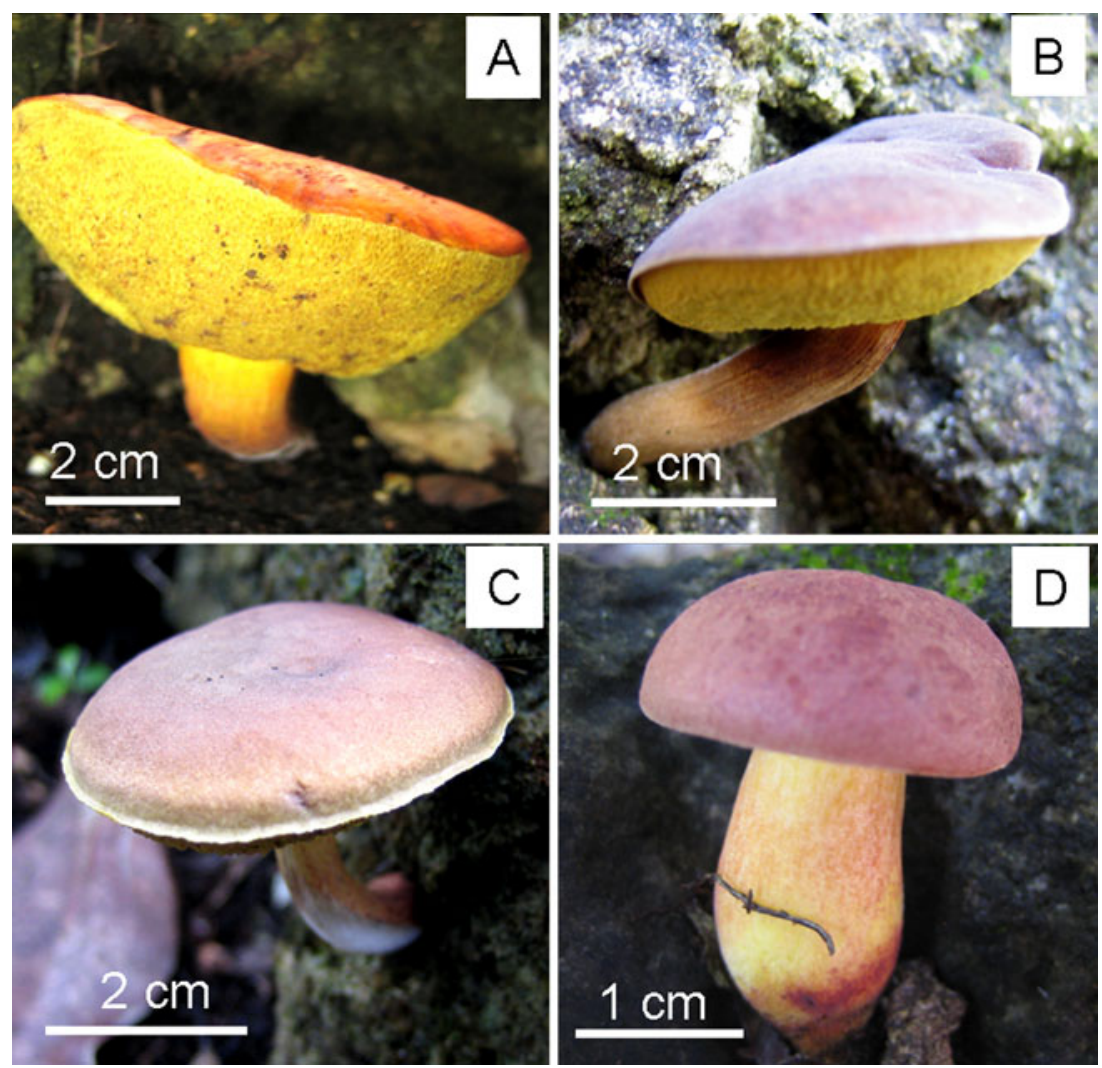

\section{Discussion}

Contrary to the traditional belief that tropical forests are impoverished in fungal species forming EM associations, recent mycological studies in tropical forests have revealed

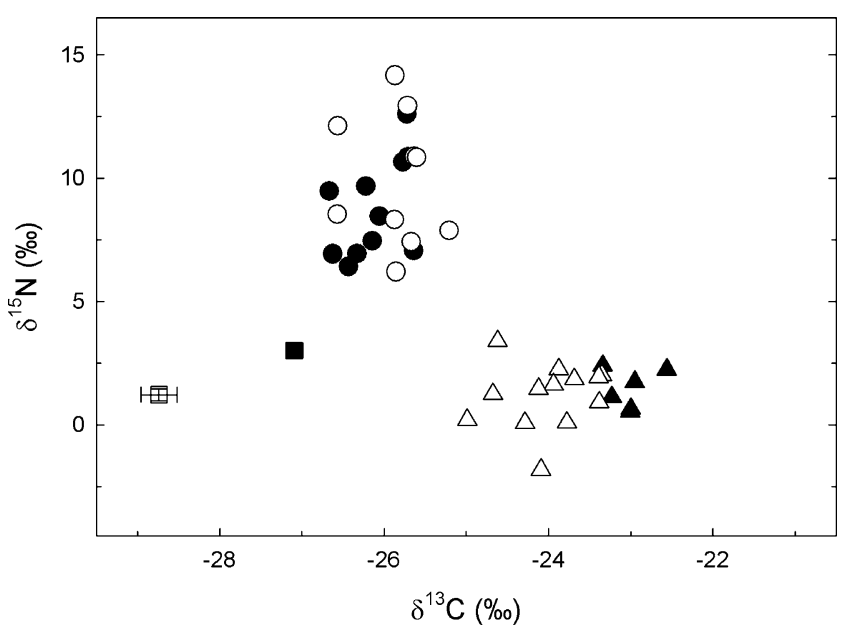

Fig. 2 Nitrogen and carbon isotope values for fungal fruiting bodies collected in a seasonally dry tropical forest on the Northern Yucatan Peninsula, Mexico. Open circles, boletes collected in $2001(n=10)$; closed circles, boletes collected in $2005(n=10)$; filled triangles, wood-decomposing fungi $(n=6)$; open triangles, litter-decomposing fungi ( $n=13)$; open square, mean $( \pm \mathrm{SE})$ foliage $(n=18)$; closed squares, mean $( \pm \mathrm{SE})$ soil $(n=18)$ a wide diversity of EM fungi. For instance, the Dipterocarpaceae forests in Southeast Asia have been shown to be associated with various EM fungal genera (Natarajan et al. 2005; Smits 1992; Watling and Lee 1995) as have forests dominated by EM leguminous trees in western Guyana (Henkel et al. 2002). However, the majority of these studies have been conducted in wet tropical forests and/or in forest patches that are characterized by a single tree species that occupies $80 \%$ or more of the trunk basal area (Connell and Lowman 1989; Henkel et al. 2002; Natarajan et al. 2005; Newbery et al. 1988). Few studies have been conducted in lowland SDTF (Brundrett et al. 1996; Högberg 1992; Thoen and Ba 1989), and to our knowledge, no studies have examined the occurrence of EM fungi in the highly diverse, lowland SDTF on the Yucatan Peninsula. Despite the lack of similarity to known species, the low $\delta^{13} \mathrm{C}$ and high $\delta^{15} \mathrm{~N}$ signature of bolete fruiting bodies relative to cooccurring saprotrophic fungi were highly suggestive of an ectomycorrhizal trophic status for these boletes. Our results not only provide the first isotopic evidence of the ectomycorrhizal status of boletes on the Northern Yucatan Peninsula, they also complement the recent review by Mayor et al. (2009) by providing the first isotopic data for EM fungi in a SDTF in general.

Given the limited number of mycological studies in this area, it is not surprising that we were unable to identify these boletes to known species. It is estimated that 7,000- 
Table 1 Mean $( \pm \mathrm{SE}) \delta^{15} \mathrm{~N}$ and $\delta^{13} \mathrm{C}$ values for foliage, soil, bolete, wood-decomposing, and litter-decomposing fungi collected at El Eden Ecological Reserve, Mexico in 2005

\begin{tabular}{|c|c|c|}
\hline & $\delta^{15} \mathrm{~N}(\%)$ & $\delta^{13} \mathrm{C}(\%)$ \\
\hline Bolete fungi (11) & $8.77 \pm 0.61$ & $-26.12 \pm 0.11$ \\
\hline Bolete sp. 1 (1) & 9.66 & -26.22 \\
\hline Bolete sp. 2 (1) & 6.41 & -26.43 \\
\hline Bolete sp. 3 (3) & $7.61 \pm 0.45$ & $-26.27 \pm 0.18$ \\
\hline Bolete sp. 4 (6) & $9.60 \pm 0.92$ & $-25.97 \pm 0.17$ \\
\hline Wood-decomposing fungi (6) & $1.45 \pm 0.32$ & $-23.01 \pm 0.11$ \\
\hline Cookeina speciosa & 0.65 & -23.00 \\
\hline Cyathus colensoi & 0.54 & -23.01 \\
\hline Marasmiellus cubensis & 1.13 & -23.23 \\
\hline Scutellinia scutellata & 2.38 & -23.34 \\
\hline Trametes villosa & 2.24 & -22.56 \\
\hline Xylaria coccophora & 1.74 & -22.95 \\
\hline Litter-decomposing fungi (13) & $1.17 \pm 0.32$ & $-24.01 \pm 0.14$ \\
\hline Agaricus sp. 1 & 2.25 & -23.88 \\
\hline Agaricus sp. 2 & 0.20 & -24.99 \\
\hline Agaricus sp. 3 & 1.46 & -24.12 \\
\hline Agaricus sp. 4 & 0.07 & -24.28 \\
\hline Coprinus sp. 1 & 2.01 & -23.35 \\
\hline Coprinus sp. 2 & 1.64 & -23.94 \\
\hline Coprinus sp. 3 & 1.94 & -23.39 \\
\hline Leucocoprinus birnbaumii & 1.85 & -23.68 \\
\hline Marasmius haematocephalus & 0.08 & -23.77 \\
\hline Pholiota sp. 1 & 3.39 & -24.62 \\
\hline Pholiota sp. 2 & -1.83 & -24.09 \\
\hline Psathyrella sp. 1 & 1.25 & -24.68 \\
\hline Psathyrella sp. 2 & 0.91 & -23.38 \\
\hline Foliage (18) & $1.22 \pm 0.24$ & $-28.74 \pm 0.22$ \\
\hline Caesalpinia gaumeri (3) & $0.21 \pm 0.19$ & $-28.25 \pm 0.65$ \\
\hline Coccoloba diversifolia (3) & $1.42 \pm 0.11$ & $-29.63 \pm 0.34$ \\
\hline Esenbeckia pentaphylla (3) & $2.68 \pm 0.37$ & $-29.41 \pm 0.52$ \\
\hline Lonchocarpus castilloi (3) & $1.82 \pm 0.06$ & $-28.32 \pm 0.52$ \\
\hline Lysiloma latisiliquum (3) & $1.28 \pm 0.36$ & $-28.30 \pm 0.67$ \\
\hline Vitex gaumeri (3) & $-0.11 \pm 0.18$ & $-28.55 \pm 0.28$ \\
\hline Soil (18) & $3.01 \pm 0.25$ & $-27.09 \pm 0.10$ \\
\hline
\end{tabular}

Values in parentheses represent the number of independent collection for each taxon

10,000 species of fungi form EM associations worldwide (Taylor and Alexander 2005), many of which remain undescribed and likely inhabit poorly studied tropical ecosystems, such as lowland SDTF. For instance, recent mycological studies throughout the Caribbean region have found a number of previously undescribed EM species (Halling and Mueller 1999; see Ortiz-Santana et al. 2007). Additionally, the erratic nature in fruiting body production makes it difficult to study putative EM taxa. During 15 years of research at our site, we have only observed bolete fruiting bodies twice. Thus, the combination of few mycological studies, along with the sporadic nature of boletes fruiting body production, may help explain why we were unable to identify these boletes to known species using local taxonomical keys (Guzman 2003) as well as molecular techniques.

Bolete fruiting bodies were highly enriched in ${ }^{15} \mathrm{~N}$ compared to other ecosystem compartments. On average, the $\delta^{15} \mathrm{~N}$ signature of bolete fruiting bodies was $6.3 \%$ higher than that of soil, which is similar to the $6.2 \%$ enrichment of EM fungi relative to soil reported by Kohzu et al. (1999). The $\delta^{15} \mathrm{~N}$ signature of boletes was also significantly higher compared to plant foliage and saprotrophic fungi (Table 1). Fractionation against the heavier isotope during the assimilation and transfer of nitrogen from EM fungi to host plants has been proposed to explain why EM fungi are often enriched in ${ }^{15} \mathrm{~N}$ relative host plant foliage (Högberg et al. 1999b; Kohzu et al. 2000; Taylor et al. 1997). Additionally, mycelium morphology and repeated cycling of nitrogen may help explain high $\delta^{15} \mathrm{~N}$ values in EM fungi (Hobbie and Agerer 2010; Trudell et al. 2004). In contrast, the absence of nitrogen transfer to plants by saprotrophic fungi causes them appear $\delta^{15} \mathrm{~N}$ depleted relative to co-occurring EM fungi. Thus, the highly enriched $\delta^{15} \mathrm{~N}$ signature of bolete fruiting bodies relative to both saprotrophic fungi and tree foliage (Table 1) strongly supports an ectomycorrhizal trophic status for these boletes species.

Carbon isotopes have also been used to determine the trophic status for unknown species and are thought to be a more reliable indicator of the fungal trophic status than nitrogen isotopes (Hobbie et al. 2001). Differences in the $\delta^{13} \mathrm{C}$ signature of EM and saprotrophic fungi are mainly attributed to fundamental differences in carbon sources (e.g., plant photosynthate vs. detritus) (Henn and Chapela 2001; Högberg et al. 1999a). Because EM fungi receive carbon from their host plant, the $\delta^{13} \mathrm{C}$ signature of $\mathrm{EM}$ fungi tends to be more similar to the $\delta^{13} \mathrm{C}$ signature of plant foliage relative to saprotrophic fungi, which are often enriched in ${ }^{13} \mathrm{C}$ relative to both plant foliage and $\mathrm{EM}$ fungi. Although bolete fruiting bodies were on average $2.8 \%$ enriched in ${ }^{13} \mathrm{C}$ relative to plant foliage, they were significantly depleted in ${ }^{13} \mathrm{C}$ relative to co-occurring saprotrophic fungi. Previous studies have shown EM fungi to be enriched in ${ }^{13} \mathrm{C}$ relative to plant foliage (Hobbie et al. 1999; Högberg et al. 1999a), and this enrichment has been attributed to the transfer of isotopically enriched sugars from the plant to EM fungi (Hobbie et al. 1999) and/or the respiration of isotopically light $\mathrm{CO}_{2}$ by EM fungi (Boutton 1996). In contrast, saprotrophic fungi were on average $2.4 \%$ enriched in ${ }^{13} \mathrm{C}$ relative to bolete fruiting bodies, which is similar to the reported 2.3\% enrichment of saprotrophic fungi relative to EM fungi across a global range of ecosystem types (Mayor 
et al. 2009). Thus, the depleted $\delta^{13} \mathrm{C}$ signature of bolete fruiting bodies relative to co-occurring saprotrophic fungi provides further evidence for an ectomycorrhizal trophic status of these boletes.

In conclusion, despite the lack of similarity to known species, isotopic analyses strongly support an ectomycorrhizal trophic status for these boletes. Our results not only provide the first isotopic evidence of EM fungi in a highly diverse SDTF on the Northern Yucatan Peninsula, they also highlight the need for further research to better understand the diversity and ecological importance of EM fungi in these forested ecosystems.

Acknowledgments We thank El Eden Ecological Reserve for their continued support and access to their research facilities. We are grateful to Juan Castillo for his help in the field. This research was supported by grants from NSF awarded to MF Allen (DEB9981607, DEB0615427, and EF0410408) and from UC MEXUS awarded to N.J. Hasselquist. The authors would also like to thank Peter Högberg and Eliza Maher Hasselquist for their useful comments on a previous draft of this work.

Open Access This article is distributed under the terms of the Creative Commons Attribution Noncommercial License which permits any noncommercial use, distribution, and reproduction in any medium, provided the original author(s) and source are credited.

\section{References}

Allen MF, Rincon E (2003) The changing global environment and the Lowland Maya: past patterns and current dynamics. In: GómezPompa A, Allen MF, Fedrick SL, Jimenez-Osornio JJ (eds) The lowland Maya: three millennia at the human-wildland interface. Haworth, New York, pp 13-29

Allen EB, Allen MF, Helm DJ, Trappe JM, Molina R, Rincon E (1995) Patterns and regulation of mycorrhizal plant and fungal diversity. Plant Soil 170:47-62

Allen EB, Allen MF, Egerton-Warburton L, Corkidi L, Gómez-Pompa A (2003) Impacts of early- and late-seral mycorrhizae during restoration in seasonal tropical forest, Mexico. Ecol Appl 13:1701-1717

Bessette AE, Roody WC, Bessette AR (2000) North American boletes. University Press, New York

Boutton TW (1996) Stable carbon isotope ratios of soil organic matter and their use as indicators of vegetation and climate change. In: Yamasaki TW (ed) Mass spectrometry of soils. Dekker, New York, pp 47-82

Brundrett MC, Ashwath N, Jasper DA (1996) Mycorrhizas in the Kakadu region of tropical Australia. Plant Soil 184:159-171

Connell JH, Lowman MD (1989) Low-diversity tropical rainforests: some possible mechanisms for their existence. Am Nat 134:88119

Dennis RWG (1970) The fungus flora of Venezuela and adjacent countries. [Kew Bulletin, Additional Series Vol. 3]. Royal Botanic Garden, Kew

Gardes M, Bruns TD (1993) ITS primers with enhanced specificity for basidiomycetes: applications to the identification of mycorrhizae and rusts. Mol Ecol 2:113-118

Guzman G (2003) Los Hongos de El Eden Quintana Roo (Introduccion a la micobiota tropical de Mexico). INECOL y CONABIO, Mexico
Halling RE, Mueller GM (1999) New boletes from Costa Rica. Mycologia 91:893-899

Haug I, Weiß M, Homeier J, Oberwinkler F, Kottke I (2005) Russulaceae and Thelephoraceae form ectomycorrhizas with members of the Nyctaginaceae (Caryophyllales) in the tropical mountain rain forest of southern Ecuador. New Phytol 165:923936

Henkel TW, Terborgh J, Vilgalys RJ (2002) Ectomycorrhizal fungi and their leguminous hosts in the Pakaraima Mountains of Guyana. Mycol Res 106:515-531

Henn MR, Chapela IH (2001) Ecophysiology of ${ }^{13} \mathrm{C}$ and ${ }^{15} \mathrm{~N}$ isotope fractionation in forest fungi and the roots of the saprotrophicmycorrhizal divide. Oecologia 128:480-487

Hobbie EA, Agerer R (2010) Nitrogen isotopes in ectomycorrhizal sporocarps correspond to belowground exploration types. Plant Soil 327:71-83

Hobbie EA, Macko SA, Shugart HH (1999) Insights into nitrogen and carbon dynamics of ectomycorrhizal and saprotrophic fungi from isotopic evidence. Oecologia 118:353-360

Hobbie EA, Weber NS, Trappe JM (2001) Mycorrhizal vs. saprotrophic status of fungi: the isotopic evidence. New Phytol 150:601-610

Högberg P (1992) Root symbioses of trees in African dry tropical forests. J Veg Sci 3:393-400

Högberg P, Plamboeck AH, Taylor AFS, Fransson PA (1999a) Natural ${ }^{13} \mathrm{C}$ abundance reveals trophic status of fungi and host-origin of carbon in mycorrhizal fungi in mixed forests. Proc Natl Acad Sci USA 96:8534-8539

Högberg P, Högberg MN, Quist ME, Ekblad A, Näsholm T (1999b) Nitrogen isotope fractionation during nitrogen uptake by ectomycorrhizal and non-mycorrhizal Pinus sylvestris. New Phytol 142:569-576

Janos DP (1983) Tropical mycorrhizas, nutrient cycles and plant growth. In: Sutton SL, Whitmore TC, Chadwick AC (eds) Tropical rain forest: ecology and management. Blackwell Scientific Publications, Oxford, pp 327-345

Kohzu A, Yoshioka T, Ando T, Takahashi M, Koba K, Wada E (1999) Natural ${ }^{13} \mathrm{C}$ and ${ }^{15} \mathrm{~N}$ abundance of field- collected fungi and their ecological implications. New Phytol 144:323-330

Kohzu A, Tateishi T, Yamada A, Koba K, Wada E (2000) Nitrogen isotope fractionation during nitrogen transport from ectomycorrhizal fungi, Suillus granulatus, to the host plant, Pinus densiflora. Soil Sci Plant Nutr 46:733-739

Lodge DJ (1996) Microorganisms. In: Regan DP, Waide RB (eds) The food web of a tropical forest. University of Chicago Press, USA, pp 53-108

Mayor JR, Schuur EAG, Henkel TW (2009) Elucidating the nutritional dynamics of fungi using stable isotopes. Ecol Lett 12:171-183

Morris MH, Pérez-Pérez MA, Smith ME, Bledsoe CS (2009) Influence of host species on ectomycorrhizal communities associated with two co-occurring oaks (Quercus spp.) in a tropical cloud forest. FEMS Microbiol Ecol 69:274-287

Natarajan K, Senthilisarasu G, Kumaresan V, Rivière T (2005) Diversity in ectomycorrhizal fungi of a dipterocarp forest in Western Ghats. Curr Sci 88:1893-1895

Newbery DM, Alexander IJ, Thomas DW, Gartlan JS (1988) Ectomycorrhizal rain-forest legumes and soil phosphorus in Korup National Park, Cameroon. New Phytol 109:433-450

Ortiz-Santana BD, Lodge DJ, Baroni TJ, Both EE (2007) Boletes from Belize and the Dominican Republic. Fungal Divers 27:247416

Pirozynski KA (1980) Interaction between fungi and plants through the ages. Can J Bot 59:1824-1827

Redhead JF (1968) Mycorrhizal associations in some Nigerian forest trees. Trans Br Mycol Soc 51:377-387 
Schultz GP (2005) Vascular flora of the El Eden Ecological Reserve, Quintana Roo, Mexico. J Torrey Bot Soc 132:311-322

Smith SE, Read DJ (2008) Mycorrhizal symbiosis, 3rd edn. Academic, Cambridge

Smits WTM (1992) Mycorrhizal studies in Dipterocarp forests in Indonesia. In: Read DJ, Lewis DH, Fitter AH, Alexander IJ (eds) Mycorrhizas in ecosystems. CAB International, Wallingford, pp 283-292

St. John TV (1980) A survey of mycorrhizal infection in an Amazonian rain forest. Acta Amazonica 10:527-533

Taylor AFS, Alexander I (2005) The ectomycorrhizal symbiosis: life in the real world. Mycologist 19:102-112

Taylor AFS, Högbom L, Högberg M, Lyon AJE, Näsholm T, Högberg P (1997) Natural ${ }^{15} \mathrm{~N}$ abundance in fruit bodies of ectomycorrhizal fungi from boreal forests. New Phytol 136:713-720
Taylor AFS, Fransson PM, Högberg P, Högberg MN, Plamboeck AH (2003) Species level patterns in ${ }^{13} \mathrm{C}$ and ${ }^{15} \mathrm{~N}$ abundance of ectomycorrhizal and saprotrophic fungal sporocarps. New Phytol 159:757-774

Tedersoo L, Sadam A, Zambrano M, Valencia R, Bahram M (2010) Low diversity and high host preference of ectomycorrhizal fungi in western Amazonia, a neotropical biodiversity hotspot. ISME J 4:465-471

Thoen D, Ba A (1989) Ectomycorrhizas and putative ectomycorrhizal fungi of Afzelia africana Sm. and Uapaca guineensis Mull. Arg. in southern Senegal. New Phytol 113:549-559

Trudell SA, Rygiewicz PT, Edmonds RL (2004) Patterns of nitrogen and carbon stable isotope ratios in macrofungi, plants and soils in two old-growth conifer forests. New Phytol 164:317-335

Watling R, Lee SS (1995) Ectomycorrhizal fungi associated with members of the Dipterocarpaceae in Peninsular Malaysia. J Trop For Sci 7:657-669 